\title{
The roles of VHL-dependent ubiquitination in signaling and cancer
}

\section{Qing Zhang ${ }^{\text {* }}$ and Haifeng Yang ${ }^{2}$ *}

1 Department of Medical Oncology, Dana-Farber Cancer Institute, Harvard Medical School, Boston, MA, USA

${ }^{2}$ Department of Cancer Biology, Lerner Research Institute, Cleveland Clinic, Cleveland, OH, USA

\section{Edited by:}

Wenyi Wei, Harvard Medical School, USA

\section{Reviewed by:}

Jian-Jun Wei, Northwestern

University, USA

Elizabeth Hopper-Borge, Fox Chase

Cancer Center, USA

\section{${ }^{*}$ Correspondence:}

Qing Zhang, Department of Medical Oncology, Dana-Farber Cancer Institute, Harvard Medical School, 450 Brookline Avenue, Mayer Building, Room 457, Boston, MA 02215, USA. e-mail: qing_zhang@dfci.harvard.edu; Haifeng Yang, Department of Cancer Biology, Lerner Research Institute, Cleveland Clinic, NB-40, 9500 Euclid Avenue, Cleveland, OH 44195, USA. e-mail:yangh2@ccf.org
The function of tumor suppressor VHL is compromised in the vast majority of clear cell renal cell carcinoma, and its mutations or loss of expression was causal for this disease. $\mathrm{pVHL}$ was found to be a substrate recognition subunit of an E3 ubiquitin ligase, and most of the tumor-derived mutations disrupt this function. pVHL was found to bind to the alpha subunits of hypoxia-inducible factor (HIF) and promote their ubiquitination and proteasomal degradation. Proline hydroxylation on key sites of HIF $\alpha$ provides the binding signal for pVHL E3 ligase complex. Beside HIF $\alpha$, several other VHL targets have been identified, including activated epidermal growth factor receptor (EGFR), RNA polymerase II subunits RPB1 and hsRPB7, atypical protein kinase C (PKC), Sprouty2, $\beta$-adrenergic receptor II, and Myb-binding protein $\mathrm{p} 160$. HIF $\alpha$ is the most well studied substrate and has been proven to be critical for pVHL's tumor suppressor function, but the activated EGFR and PKC and other $\mathrm{pVHL}$ substrates might also be important for tumor growth and drug response. Their regulations by $\mathrm{pVHL}$ and their relevance to signaling and cancer are discussed.

\section{Keywords: ubiquitin, VHL, HIF, ccRCC, EGFR, proline hydroxylation}

von HIPPEL-LINDAU (VHL), THE REGULATION OF THE ALPHA SUBUNITS OF HYPOXIA-INDUCIBLE FACTOR, AND OXYGEN SENSING

Loss of function of the tumor suppressor gene VHL is causal in the pathogenesis of clear cell renal cell carcinoma (ccRCC). The vast majority (70-80\%) of sporadic RCCs are pathologically characterized as ccRCC. Among them, approximately $70 \%$ harbor biallelic inactivation of $V H L$ through mutation, deletion, or hypermethylation of promoter (Kaelin, 2002; Linehan and Zbar, 2004). Inherited germline mutations in $V H L$ predispose these patients to bilateral kidney cancer earlier than the sporadic kidney cancer patients, since the loss of the remaining wild type allele occurs more readily than the loss of two alleles. The protein product of the VHL tumor suppressor gene, pVHL, is found to be the substrate recognition unit of an E3 ubiquitin ligase complex that contains Cullin 2 (Cul2), Elongin B and C, and Rbx1 (Kamura et al., 1999a,b). Interestingly, tumor-derived point mutations were found to cluster around substrate recognizing ( $\beta$ domain) or the Elongin C-binding ( $\alpha$ domain) sites (Stebbins et al., 1999), stressing the importance of ubiquitin ligase activity to pVHL's tumor suppressor function. This complex targets the $\alpha$ subunits of the heterodimeric transcription factor hypoxia-inducible factor (HIF) for ubiquitination and proteasome-mediated degradation (Ohh et al., 2000). In addition to being a part of an E3 ubiquitin ligase complex, pVHL also regulates other HIF-independent biological processes such as inhibition of NF- $\mathrm{kB}$ activity (Yang et al., 2007), maintenance of chromosome stability (Thoma et al., 2009), and promoting cilia production (Schraml et al., 2009), which will not be reviewed in this article.
The best-characterized substrates for $\mathrm{pVHL}$-containing ubiquitin ligase are the alpha subunits of the HIF transcription factor. HIF contains two subunits: the oxygen-sensitive alpha subunits (HIF $1 \alpha$, HIF $2 \alpha$, and HIF $3 \alpha$, for the simplicity they will be collectively called $\mathrm{HIF} \alpha$ ) and the constitutively expressed HIF $1 \beta$ subunit [also called the aryl hydrocarbon nuclear translocator (ARNT); Semenza, 2007]. pVHL recognizes the HIF $\alpha$ only after they are hydroxylated on either of two critical prolyl residues by members of the EglN family (also called PHDs or HPHs; Epstein et al., 2001; Ivan et al., 2001, 2002; Jaakkola et al., 2001). These enzymes require molecular oxygen, $\mathrm{Fe}(\mathrm{II})$ and 2-oxoglutarate for activity. Under normal oxygen tension (normoxia), the critical proline residues on $\mathrm{HIF} \alpha$ subunits are hydoxylated (P402 and 564 on HIF1 $\alpha$ ), recognized by pVHL, poly-ubiquitinated, and destroyed by the proteasome. When the oxygen is deprived (hypoxia) by physiological or pathological conditions, the HIF $\alpha$ subunits will be produced but cannot be prolyl hydroxylated. They escape the recognition by pVHL, accumulate, and hetero-dimerize with HIF1 $\beta$. The heterodimer enters nucleus, recruit transcriptional coactivator complexes (Arany et al., 1996; Ema et al., 1999), and regulate the expression of (inducing or suppressing) hundreds of target genes by binding to the hypoxia-response element (HRE; Semenza, 2003; Figure 1). Activation of HIF leads to physiological adaptations to the deprivation of oxygen: a metabolic shift to anaerobic glycolysis, increased secretion of pro-angiogenesis factors that leads to growth of blood vessels and increased blood supply, remodeling of the extracellular matrix, and resistance to apoptosis and increased mobility. In VHL-defective ccRCC tumors, enhanced angiogenesis and constitutive activation of the HIF pathway are 


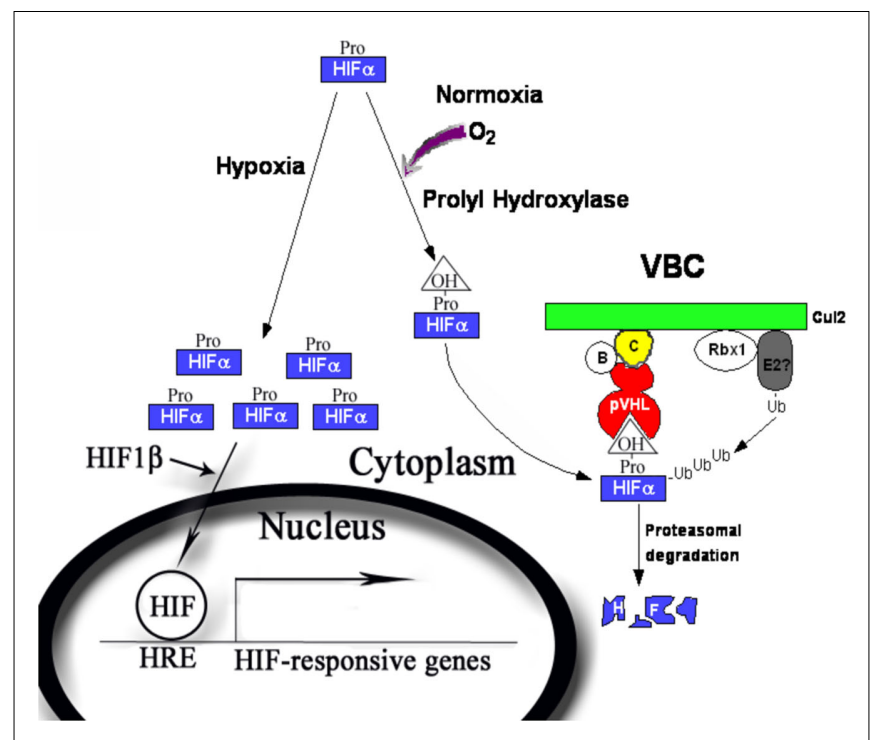

FIGURE 1 |The regulation of the HIF $\alpha$ by pVHL-containing E3 ubiquitin ligase complex. During normoxia, HIF $\alpha$ is produced and prolyl hydroxylated by PHD1-3. The hydroxyproline provides a binding signal for $\mathrm{pVHL}$, which leads to efficient ubiquitylation and proteasomal degradation of HIF $\alpha$ protein. During hypoxia, HIF $\alpha$ is not prolyl hydroxylated and escapes $\mathrm{pVHL}$ recognition. HIF $\alpha$ accumulates and forms complex with HIF1 $\beta$, goes into nucleus and turns on a transcriptional program to cope with the short-term and long-term effects of oxygen deprivation.

prominent features even when the oxygen supply is not limited. In the xenograft models of ccRCC, constitutive HIF activation was both sufficient (Kondo et al., 2002) and necessary for tumor growth (Kondo et al., 2003; Zimmer et al., 2004). In the clinic trials, drugs that block the activities of the receptors for vascular endothelial growth factor (VEGF), a critical HIF target gene, produced clear and positive, albeit often transient, clinical outcomes in kidney cancer patients (Rini, 2005).

Interestingly, although HIF $2 \alpha$ is a potent oncogene, the activations of HIF targets are not necessarily all tumor-promoting events. HIF-dependent activation of REDD1 suppressed mTORC1 (Kucejova et al., 2011), and HIF-dependent activation of JARID1C decreased the overall level of the trimethylated histone H3 lysine 4 (H3K4Me3; Niu et al., 2012). Both were tumor-suppressive events, and kidney tumors found clever ways to inactivate them (Dalgliesh et al., 2010; Kucejova et al., 2011). Further careful analysis of how HIF targets contribute to kidney tumor growth and maintenance might yield new ways to treat kidney cancer.

\section{ACTIVATED EPIDERMAL GROWTH FACTOR RECEPTOR}

It is known that HIF can enhance epidermal growth factor receptor (EGFR) activity to promote tumor growth (de Paulsen et al., 2001; Franovic et al., 2007). In VHL-defective ccRCC cells, the expression of transforming growth factor- $\alpha$ (TGF- $\alpha$ ), an agonist to EGFR, is induced by HIF $2 \alpha$. This stimulates cell proliferation through an autocrine loop (de Paulsen et al., 2001). At the same time, constitutively active HIF2 $\alpha$ also increases the translational efficiency of EGFR mRNA (Franovic et al., 2007). Increased EGFR expression and elevated TGF- $\alpha$ work together to promote autonomous growth (cellular growth in the absence of stimulating growth factors), which is a hallmark of cancer. Stable suppression of EGFR by shRNAs prevents serum-free growth of $V H L$-defective ccRCC cells in vitro, and retards the tumor growth of these cells for extended periods in vivo without affecting HIF $2 \alpha$ functions (Smith et al., 2005; Lee et al., 2008). This suggests that EGFR is critical for the tumor growth of $V H L$-defective ccRCC cells and could be a good therapeutic target in kidney cancer.

Epidermal growth factor receptor is implicated in many human cancers, as activating mutations of EGFR have been identified in human glioblastoma, non-small cell lung carcinomas (NSCLC), and colon cancer. Upon ligand binding, EGFR and its family members homo- or hetero-dimerize, trans-phosphorylate the c-terminal tyrosine residues. These phosphorylated residues recruit signaling molecules, which activate downstream effectors and elicit biological responses (Yarden and Sliwkowski, 2001). Ras/Raf/MEK/ERK and PI3K/PDK1/Akt1 are two major downstream pathways of activated EGFR. Since they promote both cellular proliferation and resistance to apoptosis (Jorissen et al., 2003), failure to turn off the activated EGFR can drive tumorigenesis.

Endocytosis and lysosome-mediated degradation is reported to be the major mechanism to down-regulate the activated EGFR. By binding to EGFR either directly through phosphorylated Y1045 (Levkowitz et al., 1999) or through its association with another EGFR-interacting protein Grb2 (Waterman et al., 2002), the ubiquitin ligase $\mathrm{c}-\mathrm{Cbl}$ promotes its ubiquitination (Levkowitz et al., 1998). c-Cbl promotes mono-ubiquitylation on multiple lysine residues of EGFR, which is sufficient for EGFR endocytosis and degradation (Haglund et al., 2003a,b; Mosesson et al., 2003), However, mass-spectrometric and western blot analyses have suggested that a fraction of activated EGFR is poly-ubiquitinated (Huang et al., 2006; Umebayashi et al., 2008). Thus it is possible that other E3 ubiquitin ligases add poly-ubiquitin to the activated EGFR to promote its turnover.

Recently it was reported that pVHL was essential for the clearance of activated EGFR (Wang et al., 2009) and the proposed mechanism was that constitutively active HIF suppressed the lysosomal-mediated degradation of the activated EGFR. Specifically, Wang et al. suggested that HIF reduced the expression of Rabaptin-5. As Rabaptin-5 was critical for Rab5-mediated endosome fusion, reduced expression of Rabaptin-5 led to delayed EGFR sorting to the late endosome and lysosome, and this led to longer half-lives of the activated EGFR. This explanation predicted that delayed turnover of activated EGFR in VHL-defective ccRCC cells was due to high levels of HIF $\alpha$ subunits. However, Zhou and Yang (2011) found that the endogenous HIF was not the only or major cause of delayed EGFR turnover in VHL-defective ccRCC cells. Furthermore, they found that pVHL-mediated downregulation of the activated EGFR was mostly mediated by proteasome instead of lysosome. In addition, loss of both c-Cbl and VHL caused the activated EGFR to become completely stable during the experiment, suggesting that these ubiquitin ligases collaborated to down-regulate activated EGFR. Finally it was reported that pVHL promoted the poly-ubiquitination of the activated EGFR, and this persisted in the absence of c-Cbl. Thus in ccRCC cells, pVHL promotes the poly-ubiquitination of the activated EGFR 


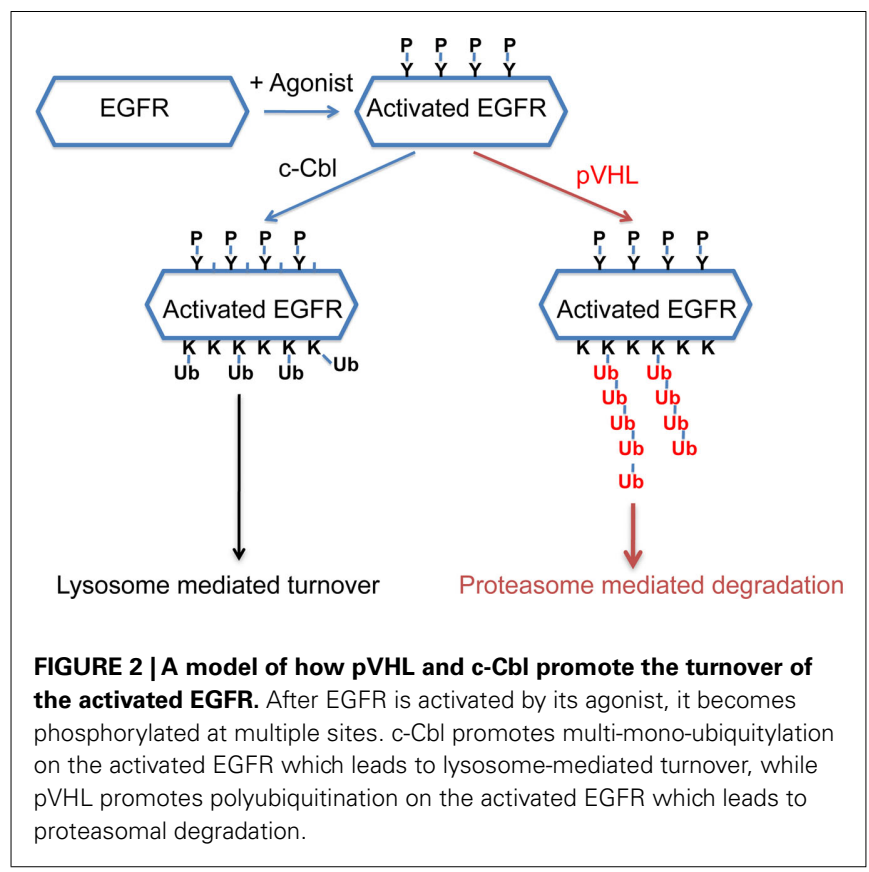

and subsequent proteasomal degradation that is independent of $\mathrm{c}-\mathrm{Cbl}$ (Figure 2). Further study is needed to determine the relative contributions of the HIF-dependent and HIF-independent mechanisms that pVHL uses to suppress activated EGFR. Nevertheless, in VHL-defective ccRCC cells, the prolonged signaling of the activated EGFR, together with elevated TGF- $\alpha$ and EGFR protein level, likely contributes to tumor growth. As the activated EGFR that is phosphorylated at some sites displayed VHL-dependent degradation (unpublished data), it is likely that pVHL-dependent polyubiquitination of activated EGFR is not a phenomenon that is unique to kidney cancer cells.

\section{RNA POLYMERASE II SUBUNITS}

Large subunit of RNA polymerase II (RPB1) is responsible for the initiation and elongation of mRNA and its activity is regulated through its c-terminal phosphorylation (Kuznetsova et al., 2003; Table 1). Through bioinformatic analysis, Kuznetsova et al. (2003) found that a fragment of RPB1 share some sequence similarity with oxygen-dependent degradation domain (ODDD) of HIF1 $\alpha$. In addition, RPB1 also contained an analogous LXXLAP sequence that was found in HIF1 $\alpha$ protein that was the site of prolyl hydroxylation that mediated recognition by $\mathrm{pVHL}$. In response to DNA damage agents or UV radiation, RPB1 underwent hyperphosphorylation and then proline hydroxylation. This led to recognition by pVHL-associated E3 ligase complex and its ubiquitination in PC12 cells. By testing the in vitro binding between RPB1 peptide and radio-labeled pVHL, they showed that hydroxylated RPB1 Proline 1465 was the major site that mediated interaction with pVHL. However, it remained to be determined whether hyperphosphorylation on RPB1 led to its proline hydroxylation. They also showed that the amount of hyperphosphorylated, but not hypophosphorylated RPB1 correlates inversely with pVHL levels in PC12 cells. These data suggests that pVHL binds to RPB1 through hydroxylated proline, promotes the ubiquitination of RPB1, and reduces hyperphosphorylated RPB1 levels in response to UV or DNA damage agents in PC12 cells.

Surprisingly, when pVHL was re-expressed in two different VHL-deficient kidney cancer cell lines, pVHL increased the level of RPB1 instead of decreasing it as expected (Mikhaylova et al., 2008). Furthermore, overexpression of wild type RPB1, not the P1465A mutant that cannot be hydroxylated, promoted tumor growth in kidney cancer cells expressing wild type VHL. Since the P1465A mutant RPB1 escapes VHL regulation, this is against the hypothesis that loss of VHL regulation on RPB1 is a tumor-promoting event. However, subsequent studies did reveal that RPB1 hydroxylation was significantly higher in kidney tumors compared to normal control. Consistent with the finding that PHD1 (EglN2, one of prolyl hydroxylases that modify HIF $\alpha$ ) was the primary hydroxylase that modifies RPB1, levels of RPB1 hydroxylation correlated with levels of PHD1 in kidney cancer (Yi et al., 2010). Thus the contribution of RPB1 hydroxylation and pVHL-dependent ubiquitination to kidney cancer remains unclear and awaits further investigation.

In addition to RPB1, $\mathrm{Na}$ et al. discovered a novel pVHLinteracting protein, human RNA polymerase II seventh subunit (hsRPB7) by performing yeast two-hybrid screening from a kidney cDNA library. hsRBP7 bound to the 54-113 amino acid regions of pVHL, a part of VHL $\beta$-domain responsible for substrate recognition ( $\mathrm{Na}$ et al., 2003). Interestingly, two representative VHL $\beta$-domain mutants $(\mathrm{P} 86 \mathrm{H}$ and $\mathrm{Y} 98 \mathrm{H})$ showed decreased binding to hsRPB7 compared to wild type. hsRBP7 underwent VHLdependent ubiquitination and proteasome-dependent degradation. As a functional readout, hsRPB7 can positively regulate VEGF expression, an effect that was ameliorated by overexpressing VHL in kidney cancer cells. However, in this paper, it was not clear whether hydroxylation would play a role in hsRBP7's degradation by pVHL E3 ligase complex. It will also be critical to identify the molecular mechanism by which hsRPB7 regulates the expression of specific genes such as VEGF.

\section{PROTEIN KINASE C}

Protein kinase $\mathrm{C}$ (PKC) is a superfamily of phospholipid-activated serine/threonine kinase. Activation of canonical PKC family members by 12-O-tetradecanoylphorbol-13-acetate (TPA) can lead to various cellular responses, such as change of cell morphology and increased cell proliferation (Hata et al., 1993; Table 1). Various PKC family members were reported to bind to VHL, and this led to their ubiquitination and degradation. Although PKC $\delta$ was found to interact with the $\beta$ domain of pVHL, its overall protein level was not affected by pVHL status (Iturrioz et al., 2006). Instead it was PKC $\zeta I$ II that was reported to be a pVHL substrate, and its c-terminus was important for VHL-dependent proteasomal degradation (Iturrioz and Parker, 2007). While wild type pVHL could promote the degradation of PKC $\zeta I$ II efficiently, some tumorderived VHL mutants (such as $\mathrm{Y} 98 \mathrm{H}, \mathrm{C162W}$, and R167W) failed to do so. However, it remained unclear whether PKC $\zeta$ II was a direct substrate for $\mathrm{pVHL}$ complex, and whether proline hydroxylation played a role in the turnover of PKC $\zeta I I$.

Protein kinase $\mathrm{C} \lambda / 4 \mathrm{RA}$ contains point mutations that render it partially and constitutively active (Akimoto et al., 1996). The active form of PKC $\lambda$ bound to PVHL tighter than its wild type 
Table 1 | A brief description of the pVHL substrates and the types of cancer they are involved in.

\begin{tabular}{|c|c|c|c|}
\hline Gene name & Biological functions & Types of cancer involved & Reference \\
\hline $\mathrm{HIF} \alpha(\mathrm{HIF} 1,2$, and $3 \alpha)$ & $\begin{array}{l}\text { Mediate transcriptional adaptation to oxygen } \\
\text { deprivation by enhancing metabolic change, } \\
\text { migration, and angiogenesis }\end{array}$ & All types of cancer & Semenza (2010) \\
\hline $\begin{array}{l}\text { EGFR (epidermal growth } \\
\text { factor receptor) }\end{array}$ & $\begin{array}{l}\text { Activate Ras/Raf/MEK/ERK and PI3K/PDK1/Akt1 } \\
\text { pathways; promote cell proliferation; and } \\
\text { resistance to apoptosis }\end{array}$ & All types of cancer & $\begin{array}{l}\text { Jorissen et al. (2003), Yarden and } \\
\text { Sliwkowski (2001) }\end{array}$ \\
\hline $\begin{array}{l}\text { RPB1 (large subunit of } \\
\text { RNA polymerase II) }\end{array}$ & $\begin{array}{l}\text { The largest subunit of RNA polymerase II, the } \\
\text { polymerase responsible for synthesizing } \\
\text { messenger RNA in eukaryotes }\end{array}$ & Kidney cancer & Yi et al. (2010) \\
\hline $\begin{array}{l}\text { RPB7 (RNA polymerase } \\
\text { II seventh subunit) }\end{array}$ & $\begin{array}{l}\text { The seventh largest subunit of RNA polymerase II } \\
\text { that reportedly increases VEGF expression }\end{array}$ & Kidney cancer & Na et al. (2003) \\
\hline $\begin{array}{l}\text { aPKC (atypical protein } \\
\text { kinase C) }\end{array}$ & $\begin{array}{l}\text { Activates MAPK and upregulate VEGF expression } \\
\text { (PKC } \delta \text { ); phosphorylates MUC1 and potentiates } \\
\beta \text {-catenin signaling (PKC } \delta \text { ); increases cancer cell } \\
\text { migration (PKC } \delta \text { ); acts as endogenous inhibitors of } \\
\text { tight junction formation (PKC } \zeta l)\end{array}$ & $\begin{array}{l}\text { Breast cancer } \\
\text { Colon cancer } \\
\text { Kidney cancer } \\
\text { Endometrial cancer }\end{array}$ & $\begin{array}{l}\text { Pal et al. (1997), Ren et al. (2002), } \\
\text { Razorenova et al. (2011), Reno et al. } \\
\text { (2008), Parkinson et al. (2004) }\end{array}$ \\
\hline SPRY2 (sprouty2) & $\begin{array}{l}\text { Antagonizes the activated receptor tyrosine } \\
\text { kinases and downregulates angiogenesis }\end{array}$ & $\begin{array}{l}\text { Breast cancer } \\
\text { Hepatocellular cancer } \\
\text { prostate cancer } \\
\text { Lung cancer } \\
\text { Colon cancer }\end{array}$ & $\begin{array}{l}\text { Lee et al. (2001), Lo et al. (2004), } \\
\text { Fong et al. (2006), McKie et al. } \\
\text { (2005), Sutterluty et al. (2007), Feng } \\
\text { et al. (2011) }\end{array}$ \\
\hline $\begin{array}{l}\beta 2 A R \text { ( } \beta \text {-adrenergic } \\
\text { receptor II) }\end{array}$ & $\begin{array}{l}\text { Mediate the catecholamine-induced activation of } \\
\text { adenylate cyclase through the action of G proteins. } \\
\text { involved in cardiovascular functions and apoptosis }\end{array}$ & Currently not known & Rockman et al. (2002) \\
\hline $\begin{array}{l}\text { MYBBP1A (Myb-binding } \\
\text { protein p160) }\end{array}$ & $\begin{array}{l}\text { May activate or repress transcription through } \\
\text { interactions with DNA-binding proteins }\end{array}$ & $\begin{array}{l}\text { Head and neck squamous } \\
\text { cell carcinoma }\end{array}$ & $\begin{array}{l}\text { Diaz et al. (2007), Tavner et al. (1998), } \\
\text { Acuna Sanhueza et al. (2012) }\end{array}$ \\
\hline
\end{tabular}

counterpart, and this led to its preferential ubiquitination by VHL E3 ligase complex (Okuda et al., 2001).

Atypical PKC $\lambda$ interacted with ASIP/PAR- 3 and PAR- 6 and was important for the maintenance of the tight junctions and the cell polarity in epithelial cells (Suzuki et al., 2001). In another epithelial cell line HC11 PKCלII was critical to maintain the cells in a non-differentiated state characterized by the absence of tight junctions and cell overgrowth (Parkinson et al., 2004). Since pVHL was reported to bind and degrade several PKC family members, it was reasonable to hypothesize that pVHL can affect actin and cytoskeletal organization, tight junction formation and cell polarity, which were often found dysregulated in cancer cells. Further study is needed to investigate the functional role of the VHL-PKCs axis in kidney cancer.

\section{SPROUTY2}

Sprouty2 (SPRY2) is one of four mammalian sprouty family members (SPRY1-4; Hacohen et al., 1998). Previous research showed that SPRY family members negatively regulated the activities of receptor tyrosine kinase and reduced angiogenesis (Lee et al., 2001; Table 1). Anderson et al. (2011) reported that hypoxia increased SPRY2 protein levels in various cancer cells, and it did so mainly through increased SPRY2 protein stability. While knockdown of PHD1 or PHD3 increased SPRY2 protein levels, overexpression of all three PHD isoforms (PHD1, 2, and 3) decreased its protein levels. By mass spectrometry, three potential prolyl hydroxylation sites were identified (P18, 144, and 160). Mutating these three Proline residues to Alanine residues significantly decreased the binding between SPRY2 and PVHL and produced more stable SPRY2 protein. Functionally, since SPRY2 was reported to have anti-migratory and anti-proliferative effect on cancer cell growth through inhibiting ERK1/2 kinase pathway (Impagnatiello et al., 2001; Yigzaw et al., 2001), suppressing either PHD1 or pVHL blunted the effect of FGF-induced ERK kinase pathway due to increased SPRY2 protein level. In a subset of hepatocellular carcinoma, $\mathrm{pVHL}$ protein levels were upregulated, and this led to decrease of SPRY2 protein that contributed to cancer progression (Lin et al., 2008). However, about $70 \%$ renal cell carcinomas have defects in pVHL. If the SPRY2 protein levels are upregulated in these tumors as expected, it will be intriguing to find out how this would impact tumorigenesis.

\section{$\beta_{2}$-ADRENERGIC RECEPTOR}

$\beta_{2}$-adrenergic receptor $\left(\beta_{2} \mathrm{AR}\right)$ is one of the G-protein-coupled receptors (GPCRs). Besides generating second messengers, $\beta_{2} \mathrm{AR}$ plays an important role in control of cardiovascular functions and apoptosis (Rockman et al., 2002; Table 1). Xie et al. (2009) reported that hypoxia can stabilize $\beta_{2} \mathrm{AR}$ protein by inhibiting its ubiquitination. Further findings demonstrated that pVHL E3 ligase complex associated with $\beta_{2} \mathrm{AR}$ protein in vivo, contributing to its ubiquitination and degradation. Mechanistically, prolyl 
hydroxylase PHD3 interacted with $\beta_{2} \mathrm{AR}$ and mediated the hydroxylation of the $\beta_{2} \mathrm{AR}$ at proline residues 382 and 395 , which primed $\beta_{2} \mathrm{AR}$ recognition by $\mathrm{pVHL}$ E3 ligase complex. $\beta_{2} \mathrm{AR}$ accounts for $25-30 \%$ of total $\beta$-type adrenergic receptor in the human heart and is the predominant form of the adrenergic receptor that exists in some of smooth muscles (Johnson, 1998; Rockman et al., 2002). Interestingly, the $\beta_{2} \mathrm{AR}$ protein is highly expressed in heart in vivo, where PHD3 is also abundantly expressed (Xie et al., 2009). This poses an apparent paradox, as PHD3 is the major enzyme that modifies $\beta_{2} \mathrm{AR}$ for its degradation. It might be possible that the PHD3-dependent destruction of $\beta_{2} \mathrm{AR}$ is a regulated event and only happens with external stimuli. Although it is unclear now, the PHD3- $\beta_{2}$ AR-pVHL signaling axis might be operating in kidney cancer and merits more investigation.

\section{Myb-BINDING PR0TEIN p160 (MYBBP1A)}

Using an ICAT (isotope-coded affinity tag) quantitative proteomics technology, Lai et al. identified MYBBP1A as a novel VHL substrate. MYBBP1A is a transcriptional regulator that can activate or suppress gene transcription through interacting with DNA-binding proteins (Tavner et al., 1998; Diaz et al., 2007; Table 1). MYBBP1A was degraded by VHL in a prolyl hydroxylation dependent manner. Further research showed that MYBBP1A proline 693 site as the potential hydroxylation site that might

\section{REFERENCES}

Acuna Sanhueza, G., Faller, L., George, B., Koffler, J., Misetic, V., Flechtenmacher, C., Dyckhoff, G., Plinkert, P., Angel, P., Simon, C., and Hess, J. (2012). Opposing function of MYBBP1A in proliferation and migration of head and neck squamous cell carcinoma cells. BMC Cancer 12, 72 . doi:10.1186/1471-2407-12-72

Akimoto, K., Takahashi, R., Moriya, S., Nishioka, N., Takayanagi, J., Kimura, K., Fukui, Y., Osada, S., Mizuno, K., Hirai, S., Kazlauskas, A., and Ohno, S. (1996). EGF or PDGF receptors activate atypical PKC lambda through phosphatidylinositol 3-kinase. EMBO J. $15,788-798$.

Anderson, K., Nordquist, K. A., Gao, X., Hicks, K. C., Zhai, B., Gygi, S. P., and Patel, T. B. (2011). Regulation of cellular levels of sprouty 2 protein by prolyl hydroxylase domain and von HippelLindau proteins. J. Biol. Chem. 286, $42027-42036$

Arany, Z., Huang, L. E., Eckner, R., Bhattacharya, S., Jiang, C., Goldberg, M. A., Bunn, H. F., and Livingston, D. M. (1996). An essential role for p300/CBP in the cellular response to hypoxia. Proc. Natl. Acad. Sci. U.S.A. 93, 12969-12973.

Dalgliesh, G. L., Furge, K., Greenman, C., Chen, L., Bignell, G., Butler, A., Davies, H., Edkins, S., Hardy,

trigger the interaction with VHL and subsequent degradation (Lai et al., 2011). It remains largely unknown how MYBBP1A might contribute to kidney cancer.

\section{SUMMARY}

Proline hydroxylation on HIF $\alpha$ proteins led to their recognition by pVHL, followed by very efficient ubiquitination and proteasomal degradation. Without a functional VHL, HIF pathway is strongly and constitutively active. So far this has been proved to be the most significant and clinically useful tumor suppressor function of pVHL. However, although proline hydroxylation on RPB1, SPRY2, and $\beta_{2} \mathrm{AR}$ also led to PVHL-dependent ubiquitination, this did not automatically cause protein degradation as the ubiquitin chain linkages on them might be different. It is also unclear whether SPRY2 and $\beta_{2} \mathrm{AR}$ are more abundant in VHL-defective renal cancer cells and whether they contribute to tumor growth or maintenance at all.

Interestingly, it is the active forms of EGFR and atypical PKC that are ubiquitinated by pVHL and targeted for degradation. As these kinases have pro-proliferating and anti-survival activities, it is possible that their degradation is also important to pVHL's tumor suppressor function. It remains to be tested whether protein phosphorylations, in addition to proline hydroxylation, also constitute a recognition signal for pVHL.

Ema, M., Hirota, K., Mimura, J., Abe, H., Yodoi, J., Sogawa, K., Poellinger, L., and Fujii-Kuriyama, Y. (1999). Molecular mechanisms of transcription activation by HLF and HIFlalpha in response to hypoxia: their stabilization and redox signal-induced interaction with $\mathrm{CBP} / \mathrm{p} 300$. EMBO J. 18, 1905-1914.

Epstein, A. C., Gleadle, J. M., McNeill, L. A., Hewitson, K. S., O'Rourke, J., Mole, D. R., Mukherji, M., Metzen, E., Wilson, M. I., Dhanda, A., Tian, Y. M., Masson, N., Hamilton, D. L., Jaakkola, P., Barstead, R., Hodgkin, J., Maxwell, P. H., Pugh, C. W., Schofield, C. J., and Ratcliffe, P. J. (2001). C. elegans EGL-9 and mammalian homologs define a family of dioxygenases that regulate HIF by prolyl hydroxylation. Cell 107, 43-54.

Feng, Y. H., Wu, C. L., Tsao, C. J., Chang, J. G., Lu, P. J., Yeh, K. T., Uen, Y. H., Lee, J. C., and Shiau, A. L. (2011). Deregulated expression of sprouty2 and microRNA-21 in human colon cancer: correlation with the clinical stage of the disease. Cancer Biol. Ther. 11, 111-121.

Fong, C. W., Chua, M. S., McKie, A. B. Ling, S. H., Mason, V., Li, R., Yusoff, P., Lo, T. L., Leung, H. Y., So, S. K. and Guy, G. R. (2006). Sprouty 2 , an inhibitor of mitogen-activated protein kinase signaling, is downregulated in hepatocellular carcinoma. Cancer Res. 66, 2048-2058.
Franovic, A., Gunaratnam, L., Smith, K. Robert, I., Patten, D., and Lee, S. (2007). Translational up-regulation of the EGFR by tumor hypoxia provides a nonmutational explanation for its overexpression in human cancer. Proc. Natl. Acad. Sci. U.S.A. 104, 13092-13097.

Hacohen, N., Kramer, S., Sutherland, D., Hiromi, Y., and Krasnow, M. A. (1998). sprouty encodes a novel antagonist of FGF signaling that patterns apical branching of the Drosophila airways. Cell 92, 253-263.

Haglund, K., Di Fiore, P. P., and Dikic, I. (2003a). Distinct monoubiquitin signals in receptor endocytosis. Trends Biochem. Sci. 28, 598-603.

Haglund, K., Sigismund, S., Polo, S., Szymkiewicz, I., Di Fiore, P. P., and Dikic, I. (2003b). Multiple monoubiquitination of RTKs is sufficient for their endocytosis and degradation. Nat. Cell Biol. 5, 461-466.

Hata, A., Akita, Y., Suzuki, K., and Ohno, S. (1993). Functional divergence of protein kinase $\mathrm{C}$ (PKC) family members. PKC gamma differs from PKC alpha and -beta II and $\mathrm{nPKC}$ epsilon in its competence to mediate-12-O-tetradecanoyl phorbol 13-acetate (TPA)-responsive transcriptional activation through a TPA-response element. J. Biol. Chem. 268, 9122-9129. 
Huang, F., Kirkpatrick, D., Jiang, X., Gygi, S., and Sorkin, A. (2006). Differential regulation of EGF receptor internalization and degradation by multiubiquitination within the kinase domain. Mol. Cell 21, 737-748.

Impagnatiello, M. A., Weitzer, S., Gannon, G., Compagni, A., Cotten, M., and Christofori, G. (2001). Mammalian sprouty-1 and -2 are membrane-anchored phosphoprotein inhibitors of growth factor signaling in endothelial cells. J. Cell Biol. 152, 1087-1098.

Iturrioz, X., Durgan, J., Calleja, V., Larijani, B., Okuda, H., Whelan, R., and Parker, P. J. (2006). The von HippelLindau tumour-suppressor protein interaction with protein kinase $\mathrm{C}$ delta. Biochem. J. 397, 109-120.

Iturrioz, X., and Parker, P. J. (2007). PKCzetaII is a target for degradation through the tumour suppressor protein pVHL. FEBS Lett. 581, 1397-1402.

Ivan, M., Haberberger, T., Gervasi, D. C., Michelson, K. S., Gunzler, V., Kondo, K., Yang, H., Sorokina, I., Conaway, R. C., Conaway, J. W., and Kaelin, W. G. Jr. (2002). Biochemical purification and pharmacological inhibition of a mammalian prolyl hydroxylase acting on hypoxia-inducible factor. Proc. Natl. Acad. Sci. U.S.A. 99, 13459-13464.

Ivan, M., Kondo, K., Yang, H., Kim, W., Valiando, J., Ohh, M., Salic, A., Asara, J. M., Lane, W. S., and Kaelin, W. G. Jr. (2001). HIFalpha targeted for VHL-mediated destruction by proline hydroxylation: implications for O2 sensing. Science 292, 464-468.

Jaakkola, P., Mole, D. R., Tian, Y. M., Wilson, M. I., Gielbert, J., Gaskell, S. J., Kriegsheim, A., Hebestreit, H. F., Mukherji, M., Schofield, C. J., Maxwell, P. H., Pugh, C. W., and Ratcliffe, P. J. (2001). Targeting of HIF-alpha to the von HippelLindau ubiquitylation complex by O2-regulated prolyl hydroxylation. Science 292, 468-472.

Johnson, M. (1998). The betaadrenoceptor. Am. J. Respir. Crit. Care Med. 158, S146-S153.

Jorissen, R. N., Walker, F., Pouliot, N., Garrett, T. P., Ward, C. W., and Burgess, A. W. (2003). Epidermal growth factor receptor: mechanisms of activation and signalling. Exp. Cell Res. 284, 31-53.

Kaelin, W. G. Jr. (2002). Molecular basis of the VHL hereditary cancer syndrome. Nat. Rev. Cancer 2, 673-682.

Kamura, T., Conrad, M. N., Yan, Q., Conaway, R. C., and Conaway, J. W. (1999a). The Rbxl subunit of SCF and VHL E3 ubiquitin ligase activates Rub1 modification of cullins Cdc53 and Cul2. Genes Dev. 13, 2928-2933.

Kamura, T., Koepp, D. M., Conrad, M. N., Skowyra, D., Moreland, R. J., Iliopoulos, O., Lane, W. S., Kaelin, W. G. Jr., Elledge, S. J., Conaway, R. C., Conaway, R. C., Harper, J. W., and Conaway, J. W. (1999b). Rbx1, a component of the VHL tumor suppressor complex and SCF ubiquitin ligase. Science 284, 657-661.

Kondo, K., Kim, W. Y., Lechpammer, M., and Kaelin, W. G. Jr. (2003). Inhibition of HIF2alpha is sufficient to suppress pVHL-defective tumor growth. PLoS Biol. 1, E83. doi:10.1371/journal.pbio.0000083

Kondo, K., Klco, J., Nakamura, E., Lechpammer, M., and Kaelin, W. G. Jr. (2002). Inhibition of HIF is necessary for tumor suppression by the von Hippel-Lindau protein. Cancer Cell 1, 237-246.

Kucejova, B., Pena-Llopis, S., Yamasaki, T., Sivanand, S., Tran, T. A., Alexander, S., Wolff, N. C., Lotan, Y., Xie, X. J., Kabbani, W., Kapur, P., and Brugarolas, J. (2011). Interplay between pVHL and mTORC1 pathways in clear-cell renal cell carcinoma. Mol. Cancer Res. 9, 1255-1265.

Kuznetsova, A. V., Meller, J., Schnell, P. O., Nash, J. A., Ignacak, M. L., Sanchez, Y., Conaway, J. W., Conaway, R. C., and CzyzykKrzeska, M. F. (2003). von HippelLindau protein binds hyperphosphorylated large subunit of RNA polymerase II through a proline hydroxylation motif and targets it for ubiquitination. Proc. Natl. Acad. Sci. U.S.A. 100, 2706-2711.

Lai, Y., Qiao, M., Song, M., Weintraub, S. T., and Shiio, Y. (2011). Quantitative proteomics identifies the Mybbinding protein p160 as a novel target of the von Hippel-Lindau tumor suppressor. PLoS One 6, e16975. doi: 10.1371/journal.pone.0016975

Lee, S. H., Schloss, D. J., Jarvis, L., Krasnow, M. A., and Swain, J. L. (2001). Inhibition of angiogenesis by a mouse sprouty protein. J. Biol. Chem. 276, 4128-4133.

Lee, S. J., Lattouf, J. B., Xanthopoulos, J., Linehan, W. M., Bottaro, D. P., and Vasselli, J. R. (2008). von HippelLindau tumor suppressor gene loss in renal cell carcinoma promotes oncogenic epidermal growth factor receptor signaling via Akt-1 and MEK-1. Eur. Urol. 54, 845-853.

Levkowitz, G., Waterman, H., Ettenberg, S. A., Katz, M., Tsygankov, A. Y., Alroy, I., Lavi, S., Iwai, K., Reiss, Y., Ciechanover, A., Lipkowitz, S., and
Yarden, Y. (1999). Ubiquitin ligase activity and tyrosine phosphorylation underlie suppression of growth factor signaling by c-Cbl/Sli-1. Mol. Cell 4, 1029-1040.

Levkowitz, G., Waterman, H., Zamir, E., Kam, Z., Oved, S., Langdon, W. Y., Beguinot, L., Geiger, B., and Yarden, Y. (1998). c-Cbl/Sli-1 regulates endocytic sorting and ubiquitination of the epidermal growth factor receptor. Genes Dev. 12, 3663-3674.

Lin, F., Shi, J., Liu, H., Zhang, J., Zhang, P. L., Wang, H. L., Yang, X. J., and Schuerch, C. (2008). Immunohistochemical detection of the von Hippel-Lindau gene product (pVHL) in human tissues and tumors: a useful marker for metastatic renal cell carcinoma and clear cell carcinoma of the ovary and uterus. Am. J. Clin. Pathol. 129, 592-605.

Linehan, W. M., and Zbar, B. (2004). Focus on kidney cancer. Cancer Cell 6, 223-228.

Lo, T. L., Yusoff, P., Fong, C. W., Guo, K., McCaw, B. J., Phillips, W. A., Yang, H., Wong, E. S., Leong, H. F., Zeng, Q., Putti, T. C., and Guy, G. R. (2004). The ras/mitogen-activated protein kinase pathway inhibitor and likely tumor suppressor proteins, sprouty 1 and sprouty 2 are deregulated in breast cancer. Cancer Res. 64, 6127-6136.

McKie, A. B., Douglas, D. A., Olijslagers, S., Graham, J., Omar, M. M., Heer, R., Gnanapragasam, V. J., Robson, C. N., and Leung, H. Y. (2005). Epigenetic inactivation of the human sprouty2 (hSPRY2) homologue in prostate cancer. Oncogene 24, 2166-2174.

Mikhaylova, O., Ignacak, M. L., Barankiewicz, T. J., Harbaugh, S. V., Yi, Y., Maxwell, P. H., Schneider, M., Van Geyte, K., Carmeliet, P., Revelo, M. P., Wyder, M., Greis, K. D., Meller, J., and Czyzyk-Krzeska, M. F. (2008). The von Hippel-Lindau tumor suppressor protein and Egl-9-Type proline hydroxylases regulate the large subunit of RNA polymerase II in response to oxidative stress. Mol. Cell. Biol. 28, 2701-2717.

Mosesson, Y., Shtiegman, K., Katz, M., Zwang, Y., Vereb, G., Szollosi, J., and Yarden, Y. (2003). Endocytosis of receptor tyrosine kinases is driven by monoubiquitination, not polyubiquitination. J. Biol. Chem. 278, 21323-21326.

Na, X., Duan, H. O., Messing, E. M., Schoen, S. R., Ryan, C. K., di Sant'Agnese, P. A., Golemis, E. A., and $\mathrm{Wu}, \mathrm{G}$. (2003). Identification of the RNA polymerase II subunit hsRPB7 as a novel target of the von
Hippel-Lindau protein. EMBO J. 22, 4249-4259.

Niu, X., Zhang, T., Liao, L., Zhou, L., Lindner, D. J., Zhou, M., Rini, B., Yan, Q., and Yang, H. (2012). The von Hippel-Lindau tumor suppressor protein regulates gene expression and tumor growth through histone demethylase JARID1C. Oncogene 31, 776-786.

Ohh, M., Park, C. W., Ivan, M., Hoffman, M. A., Kim, T. Y., Huang, L. E., Pavletich, N., Chau, V., and Kaelin, W. G. (2000). Ubiquitination of hypoxia-inducible factor requires direct binding to the beta-domain of the von Hippel-Lindau protein. Nat. Cell Biol. 2, 423-427.

Okuda, H., Saitoh, K., Hirai, S., Iwai, K., Takaki, Y., Baba, M., Minato, N., Ohno, S., and Shuin, T. (2001) The von Hippel-Lindau tumor suppressor protein mediates ubiquitination of activated atypical protein kinase C. J. Biol. Chem. 276, 43611-43617.

Pal, S., Claffey, K. P., Dvorak, H. F., and Mukhopadhyay, D. (1997). The von Hippel-Lindau gene product inhibits vascular permeability factor/vascular endothelial growth factor expression in renal cell carcinoma by blocking protein kinase C pathways. J. Biol. Chem. 272, 27509-27512.

Parkinson, S. J., Le Good, J. A., Whelan, R. D., Whitehead, P., and Parker, P. J. (2004). Identification of PKCzetaII: an endogenous inhibitor of cell polarity. EMBO J. 23, 77-88.

Razorenova, O. V., Finger, E. C., Colavitti, R., Chernikova, S. B., Boiko, A. D., Chan, C. K., Krieg, A., Bedogni, B., LaGory, E., Weissman, I. L., Broome-Powell, M., and Giaccia, A. J. (2011). VHL loss in renal cell carcinoma leads to up-regulation of CUB domain-containing protein 1 to stimulate $\mathrm{PKC}\{$ delta $\}$-driven migration. Proc. Natl. Acad. Sci. U.S.A. 108, 1931-1936.

Ren, J., Li, Y., and Kufe, D. (2002). Protein kinase $\mathrm{C}$ delta regulates function of the DF3/MUC1 carcinoma antigen in beta-catenin signaling. J. Biol. Chem. 277, 17616-17622.

Reno, E. M., Haughian, J. M., Dimitrova, I. K., Jackson, T. A., Shroyer, K. R., and Bradford, A. P. (2008). Analysis of protein kinase $\mathrm{C}$ delta (PKC delta) expression in endometrial tumors. Hum. Pathol. 39, 21-29.

Rini, B. I. (2005). VEGF-targeted therapy in metastatic renal cell carcinoma. Oncologist 10, 191-197.

Rockman, H. A., Koch, W. J., and Lefkowitz, R. J. (2002). Seventransmembrane-spanning receptors 
and heart function. Nature 415, 206-212.

Schraml, P., Frew, I. J., Thoma, C. R., Boysen, G., Struckmann, K., Krek, W., and Moch, H. (2009). Sporadic clear cell renal cell carcinoma but not the papillary type is characterized by severely reduced frequency of primary cilia. Mod. Pathol. 22, 31-36.

Semenza, G. L. (2003). Targeting HIF-1 for cancer therapy. Nat. Rev. Cancer 3, 721-732.

Semenza, G. L. (2007). Hypoxiainducible factor 1 (HIF-1) pathway. Sci. STKE 2007, cm8.

Semenza, G. L. (2010). Defining the role of hypoxia-inducible factor 1 in cancer biology and therapeutics. Oncogene 29, 625-634.

Smith, K., Gunaratnam, L., Morley, M., Franovic, A., Mekhail, K., and Lee, S. (2005). Silencing of epidermal growth factor receptor suppresses hypoxia-inducible factor-2driven VHL-/- renal cancer. Cancer Res. 65, 5221-5230.

Stebbins, C. E., Kaelin, W. G. Jr., and Pavletich, N. P. (1999). Structure of the VHL-ElonginC-ElonginB complex: implications for VHL tumor suppressor function. Science 284, 455-461.

Sutterluty, H., Mayer, C. E., Setinek, U., Attems, J., Ovtcharov, S., Mikula, M., Mikulits, W., Micksche, M., and Berger, W. (2007). Downregulation of sprouty2 in non-small cell lung cancer contributes to tumor malignancy via extracellular signal-regulated kinase pathwaydependent and -independent mechanisms. Mol. Cancer Res. 5, 509-520.

Suzuki, A., Yamanaka, T., Hirose, T., Manabe, N., Mizuno, K., Shimizu, M., Akimoto, K., Izumi, Y., Ohnishi, T., and Ohno, S. (2001). Atypical protein kinase $\mathrm{C}$ is involved in the evolutionarily conserved par protein complex and plays a critical role in establishing epithelia-specific junctional structures. J. Cell Biol. 152, 1183-1196.

Tavner, F. J., Simpson, R., Tashiro, S., Favier, D., Jenkins, N. A., Gilbert, D. J., Copeland, N. G., Macmillan, E. M., Lutwyche, J., Keough, R. A., and Ishii, S., and Gonda, T. J. (1998). Molecular cloning reveals that the p160 Myb-binding protein is a novel, predominantly nucleolar protein which may play a role in transactivation by Myb. Mol. Cell. Biol. 18, 989-1002.

Thoma, C. R., Toso, A., Gutbrodt, K. L., Reggi, S. P., Frew, I. J., Schraml, P., Hergovich, A., Moch, H., Meraldi, P., and Krek, W. (2009). VHL loss causes spindle misorientation and chromosome instability. Nat. Cell Biol. 11, 994-1001.

Umebayashi, K., Stenmark, H., and Yoshimori, T. (2008). Ubc4/5 and c-Cbl continue to ubiquitinate EGF receptor after internalization to facilitate polyubiquitination and degradation. Mol. Biol. Cell 19, 3454-3462.

Wang, Y., Roche, O., Yan, M. S., Finak, G., Evans, A. J., Metcalf, J. L., Hast, B. E., Hanna, S. C., Wondergem, B., Furge, K. A., Irwin, M. S., Kim, W. Y., Teh, B. T., Grinstein, S., Park, M.,
Marsden, P. A., and Ohh, M. (2009). Regulation of endocytosis via the oxygen-sensing pathway. Nat. Med. 15, 319-324.

Waterman, H., Katz, M., Rubin, C. Shtiegman, K., Lavi, S., Elson, A., Jovin, T., and Yarden, Y. (2002). A mutant EGF-receptor defective in ubiquitylation and endocytosis unveils a role for Grb2 in negative signaling. EMBO J. 21, 303-313.

Xie, L., Xiao, K., Whalen, E. J., Forrester, M. T., Freeman, R. S., Fong, G., Gygi, S. P., Lefkowitz, R. J., and Stamler, J. S. (2009). Oxygen-regulated beta(2)-adrenergic receptor hydroxylation by EGLN3 and ubiquitylation by pVHL. Sci. Signal. 2, ra33.

Yang, H., Minamishima, Y. A., Yan, Q., Schlisio, S., Ebert, B. L., Zhang, X. Zhang, L., Kim, W. Y., Olumi, A. F., and Kaelin, W. G. Jr. (2007). pVHL acts as an adaptor to promote the inhibitory phosphorylation of the NF-kappaB agonist Card9 by CK2 Mol. Cell 28, 15-27.

Yarden, Y., and Sliwkowski, M. X. (2001). Untangling the ErbB signalling network. Nat. Rev. Mol. Cell Biol. 2, 127-137.

Yi, Y., Mikhaylova, O., Mamedova, A., Bastola, P., Biesiada, J., Alshaikh, E., Levin, L., Sheridan, R. M., Meller, J., and Czyzyk-Krzeska, M. F. (2010). von Hippel-Lindau-dependent patterns of RNA polymerase II hydroxylation in human renal clear cell carcinomas. Clin. Cancer Res. 16, 5142-5152.

Yigzaw, Y., Cartin, L., Pierre, S., Scholich, K., and Patel, T. B. (2001). The C terminus of sprouty is important for modulation of cellular migration and proliferation. J. Biol. Chem. 276, 22742-22747.

Zhou, L., and Yang, H. (2011). The von Hippel-Lindau tumor suppressor protein promotes c-Cblindependent(poly)-ubiquitylation and degradation of the activated EGFR. PLoS ONE 6, e23936. doi:10.1371/journal.pone.0023936

Zimmer, M., Doucette, D., Siddiqui, N., and Iliopoulos, O. (2004). Inhibition of hypoxia-inducible factor is sufficient for growth suppression of VHL-/- tumors. Mol. Cancer Res. 2, 89-95.

Conflict of Interest Statement: The authors declare that the research was conducted in the absence of any commercial or financial relationships that could be construed as a potential conflict of interest.

Received: 09 January 2012; accepted: 26 March 2012; published online: 12 April 2012.

Citation: Zhang Q and Yang H (2012) The roles of VHL-dependent ubiquitination in signaling and cancer. Front. Oncol. 2:35. doi: 10.3389/fonc.2012.00035

This article was submitted to Frontiers in Molecular and Cellular Oncology, a specialty of Frontiers in Oncology. Copyright (C) 2012 Zhang and Yang. This is an open-access article distributed under the terms of the Creative Commons Attribution Non Commercial License, which permits non-commercial use, distribution, and reproduction in other forums, provided the original authors and source are credited. 